\title{
State Development Planning: Did it Create an East Asian Miracle?
}

BENJAMIN POWELL

gmubenpowell@yahoo.com

Assistant Professor of Economics, San Jose State University, San Jose, CA 95192-0114; Director, Center on Entrepreneurial Innovation, The Independent Institute 100 Swan Way Oakland, CA 94621

\begin{abstract}
East Asian countries have recorded large increases in per capita GDP over the last fifty years. Some observers have referred to this growth as an "East Asian Miracle." One popular explanation attributes the rapid growth to state led industrial development planning. This paper critically assesses the arguments surrounding state development planning and East Asia's growth. Whether the state can acquire the knowledge necessary to calculate which industries it should promote and how state development planning can deal with political incentive problems faced by planners are both examined. When we look at the development record of East Asian countries we find that to the extent development planning did exist, it could not calculate which industries would promote development, so it instead promoted industrialization. We also find that what rapid growth in living standards did occur can be better explained by free markets than state planning because, as measured in economic freedom indexes, these countries were some of the most free market in the world.
\end{abstract}

Key Words: East Asia, industrial planning, economic calculation, economic freedom, development planning

JEL classification: $\quad$ O200, O170, O530, B530, P170

East Asian countries have experienced dramatic economic development since the end of World War II. First Japan, then Taiwan, South Korea, Hong Kong, Singapore, and others, recorded large and rapid increases in per capita GDP (see Figure 1). Many attribute this success to a unique "Asian Model" of economic development (Johnson 1982, Amsden 1989, Wade 1990, Evans 1995, Stiglitz 1996, 2001, Woo-Cumings 1999). This model maintains some international market forces, but also involves heavy direction of the economy by state industrial development planning agencies.

The East Asian financial crisis of the late 1990s did not change the views of those who claim East Asia's success resulted from developmental planning. In fact, Wade $(1998,2000)$ attributes much of the blame for the crises to departures from the state directed model. ${ }^{1}$ Stiglitz and Furman (1998) and Stiglitz (1999) largely agree with Wade that rapid financial and capital market liberalization in East Asia combined with other factors to cause the crises. $^{2}$ These authors still believe that state industrial planning played a major role in East Asia's success prior to the crisis.

This paper critically examines the standard account of East Asia's success by questioning whether a model of state development planning could have created East Asia's miracle development.

Economic development that enhances consumers' standard of living is not simply about industrialization. It is about creating the right industries. If state planning is to lead to higher 


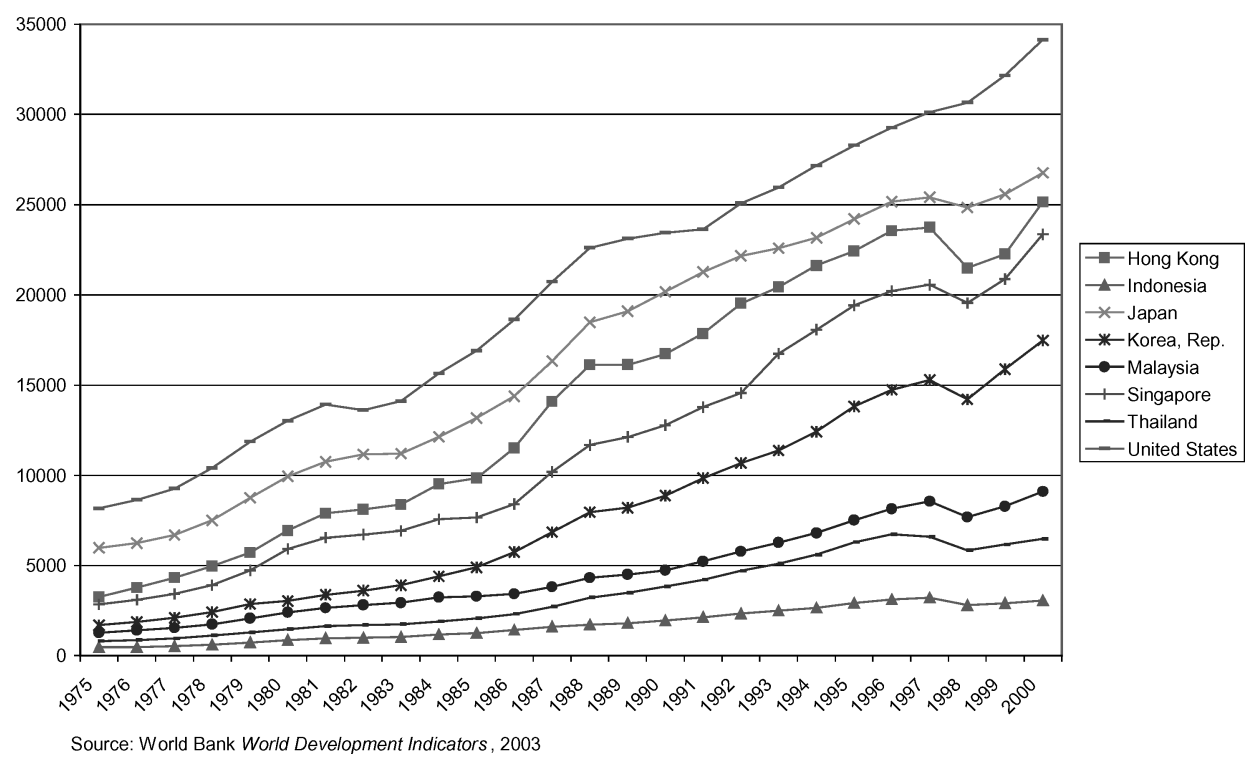

Figure 1. Per Capita GDP (PPP).

rates of economic growth, it must promote industries that will enhance consumer welfare more than the industries that would have developed in the absence of state direction. ${ }^{3}$ State development planning must somehow attain the knowledge necessary to identify which industries to promote. If these industries and their appropriate size can be calculated, promoting them over other industries more heavily represented by interest groups is also an issue. ${ }^{4}$ Both of these problems need to be overcome if industrial planning is to be used to promote development.

\section{State Development Planning}

Models of state development planning have one unique feature: they seek to promote economic development by using government agencies to identify which industries can best promote growth and allowing the agencies to intervene in the market to encourage these industries.

Johnson's (1982) book on the history of MITI and development in Japan is one early account of state development planning. Amsden's (1989) book on Korea and Evan's (1995) study on state technology promotion are others. Stiglitz (1996 and 2001) has also attributed some of East Asia's success to industrial development policies. Wade's (1990) book Governing the Market is the most completely developed theory of the East Asian developmental state. In that study Wade not only outlines what "governing the market" entails but also claims that it created the East Asian miracles in Taiwan, Korea, Japan and Hong Kong. Although authors' precise views vary, the basic developmental states they advocate are similar and confront the same problems. 
Wade describes the main features of development planning: "A pilot agency or economic general staff is one of the core features. The pilot agency decides which industries ought to exist and which industries are no longer needed in order to promote the industrial structure which enhances the nation's international competitiveness" (1990:195).

State development planning models typically view capital accumulation as a key for growth, but they do not view capital as a homogenous category like many neoclassical models. Advocates of development planning think that the government must direct both the level and composition of capital in the economy. Wade describes this process:

The GM theory, on the other hand, emphasizes capital accumulation as the principal general force for growth, and interprets superior East Asian performance as the result of a level and composition of investment different from what the FM [Free Market] or SM [Stimulated Market] policies would have produced" (Wade 1990:29).

What capital should be accumulated to produce the greatest increases in well-being? Those who advocate state development planning must answer this central question. Wade and others believe that government development planning bureaus, such as MITI in Japan, can better answer the question than a free market entrepreneurial process.

\section{Problems Confronting State Planning}

The profit and loss system informed by market prices serves as a guide to direct which industries should expand and which should contract in a market economy. Advocates of state development planning must answer how the agencies will have knowledge superior to the unhampered market and once they have it, how it will remain in the planners' interests to promote only those industries that best promote growth. The first problem will be referred to as the knowledge or calculation problem, while the second will be referred to as the public choice incentive problem. Although advocates of East Asian state development planning address the second incentive problem, they fundamentally misconstrue the nature of the knowledge problem.

\subsection{The Knowledge Problem}

A comprehensively planned rational economy is impossible. Mises (1920, 1949) showed that without private property in the means of production, prices for the means of production could not exist. Without prices, there are no relative scarcity indicators, and rational economic calculation is impossible. Hayek $(1935,1940)$ also stressed the role of the market process in generating the knowledge necessary to have an efficiently functioning economy. Hayek stressed the tacit and inarticulate knowledge that individuals possess that cannot be communicated to the central planners. With decentralized individual planning in the market, this information is used by actors while only passing on relevant information to others through actions that generate market prices (1945). Hayek shows how the market itself is the "discovery procedure" that finds new patterns of economic production that best satisfy consumer wants (1978). 
Proponents of state development planning do not advocate fully socialized planning of the economy. They specifically leave some room for functioning market prices, both in consumer and producer goods markets. Wade even says that planners must look at promoted industries' success and profitability in international markets to see if the investments were justified. But because the market generates the information needed for an efficiently functioning economy, distorting the price signals by selectively promoting individual industries undermines the very process by which the necessary information is generated. ${ }^{5}$ State planning bureaus prevent the market discovery process from operating by fixing the process to the advantage of the particular industries the government wants to support. Lavoie (1985) summarizes the problem:

The same lack of knowledge on the part of any single person or organization which makes it impossible for comprehensive planning to replace the market also makes it irrational for a noncomprehensive planning agency to try merely to "guide" the market. If the guiding agency is less knowledgeable than the system it is trying to guide—and even worse, if its actions necessarily result in further undesired consequences in the working of that system - then what is going on is not planning at all but, rather, blind interference by some agents with the plans of others (1985:95).

In the competitive process, the push and pull of resources that results from the bidding of market producers and consumers reveals which industries most urgently desire which inputs. The prices that result from this process reveal the subjective valuations of millions of consumers and producers from their individual and specific knowledge. Resources are bid into an industry because that is where they are most strongly desired. When the state actively plans development, it forces resources to particular industries. Whether it does this by taxing some and transferring to others or by rigging interventions so that market decisions direct resources to the favored industry, coercive interference is the basis. The decision-makers in the government planning bureau have no method to evaluate the opportunity cost of another industry's potential use of the resources. The opportunity cost is the subjective loss suffered by the person who would have received resources if the government had not interfered with the market process. Since the planning bureau has no way of evaluating this loss, it cannot determine if the loss in output from other industries caused by promoting one industry is greater or less than the benefit produced. The planning agency has no way to know if it is promoting development or retarding it.

Advocates of state development planning attempt to deal with the knowledge problem by collapsing it into an engineering problem. They focus on only the best and brightest planners, deny that there are correct industries to promote, or attempt to use the price mechanism to later validate government planners' decisions. None of these methods adequately addresses the central problem.

Wade characterizes how state development interventions will be evaluated by writing, "Almost certainly some of Taiwan's industries and some of its exports would not have been initially profitable without state encouragement. That they were profitable after the event reflects the use of the price mechanism to validate investment decisions taken on grounds other than current efficiency" (1990:302). "Current economic efficiency," however, is precisely the benchmark that these investments must be evaluated against. Just because a 
project that was not profitable when it was undertaken and subsidized by the government is eventually profitable does not indicate that it should have been undertaken when it was. For example, an electric toaster industry in the late 19th century U.S. could have been subsidized and created by state interventions. It would not have been profitable until at least the 1930s when more homes had electricity. Would the state have been correct for subsidizing the industry for more than thirty years? There is some relevant time frame, prior to profitability, that an industry should be created, but not too long before. The state bureaus are unable to answer how long because they cannot evaluate the opportunity cost of resources they divert.

The market can determine how far ahead a project should be undertaken. Wade often accuses the market of short sightedness, writing things such as, "Lumpy and long-term investment projects were undertaken which would probably not have been undertaken in an economy with free trade and capital movements, because they would not have been consistent with short-term profit maximization" (1990:334). ${ }^{6}$ But businesses do not focus on only short-term profit maximization. All the time they undertake long-term projects that will not be profitable for years, but they undertake them because the expected future value of those profits more than offset the temporary losses. ${ }^{7}$ Entrepreneurs discount future profits to account for this by doing net present value calculations. They also make adjustments for the uncertainty that the future project might not be successful because of changed circumstances.

It is not a sign of inefficiency that these factors cause individuals in the market not to undertake projects that the government could create through development subsidies. Time preference is a universal feature of human action, and the fact that it decreases the value of things that will only be profitable in the future does not negatively affect our level of well-being. When the government forces projects to be undertaken that would not have happened in the market because of time preference, society becomes worse off because resources for projects that could have satisfied more immediate desires are unavailable.

A government subsidized industry that eventually becomes profitable does not prove the success of the subsidy. Planners would need to know the time preference rates of consumers whose wants were not satisfied and the opportunity cost of the resources taken from other projects to subsidize the favored industry to make this claim. This data does not exist outside the very market process that the subsidies subverted. No method exists to evaluate if an industry subsidy added value to society.

The most fundamental error in the governed market's approach to solving the knowledge problem is conceiving of it as a "technical" or "engineering" problem. Wade wrote, "Investment choice has been influenced by essentially engineering concepts of take-off, linkages, gaps, substitutions, and incremental extensions-conceived in the first instance in physical rather than value terms. This reflects the importance of engineers in the planning process" (1990:188). But "value terms" create the knowledge problem.

Mises (1949) showed that technological knowledge provided by engineers only serves as a method of choosing production methods if either each factor of production is absolutely specific or all factors were perfectly substitutable for each other. If either of these conditions holds, once consumer desires were known, the production problem would become an engineering one. But in the real world neither of these conditions is true. 
Lavoie (1985) illustrates the problem by asking the reader to consider wood, which is nonspecific - it could be used for building houses or making paper. How do we choose the combination of uses that would best satisfy the demands for reading and shelter? "This is not an issue about which the engineer has any special expertise. It is not a question to which quantitative measurement of any physical dimension is relevant. It is a question of the relative value of wood in alternative uses" (1985:53). Considering only engineering concepts and technical feasibility misses the economic question of how to employ means to achieve ends such that no other more urgently felt want goes unsatisfied. Focusing state development programs on engineering concepts does not avoid the economic problem-it ignores it. To promote real increases in standards of living, the economic problem must be solved.

Advocates of development planning sometimes deny that a knowledge problem needs to be solved. Wade asserts that the "correct" industries corresponding to a country's comparative advantage are not just out there to be found, but can be made. He writes, " 'Picking Winners' implies that the potentially competitive industries are out there waiting to be discovered, as though the problem is to find those that most closely correspond with the economy's given comparative advantage. The governments of Taiwan, Korea, and Japan have not so much picked winners as made them" $(1990: 334){ }^{8}$ If a state provides a large enough subsidy, an industry can be created that would not otherwise exist. Path dependencies and positive externalities develop within the industry that may later allow it to survive without subsidy. Because the industry can later survive does not mean that development was promoted, however. Some other industry that better corresponds to the country's comparative advantage would have developed in absence of the subsidy. Real resources are used that could have better satisfied consumer wants in other industries. Krugman makes the point clear, writing, "You can't promote all domestic industries; by subsidizing one, you help it bid capital and labor away from others. So a strategic trade policy on behalf of some industries is in effect a strategic policy against others" (Krugman 1994:242). Winners must be picked, and that implies the state also must pick losers. All industrial policy decisions impose costs.

Some have suggested that "smart" people are necessary to overcome the problems planning faces. ${ }^{9}$ Even if the planners are the most brilliant people in the country, they still cannot make the calculations necessary to determine which industries should be promoted. The problem is not that someone is not smart enough, but that the relevant information is not given to any one mind. The knowledge is dispersed over all of the individuals in society and is only produced via the market process. Any attempt to go beyond the market's process simply does not have the relevant information available. Lavoie summarizes the problem by writing,

To propose that the planning agency guide and accelerate market forces is to presume that the investment-guiding agency can anticipate future developments better than the market can; it is to assume that the agency's individual intelligence exceeds the social intelligence of the competitive process. How will the investment-guiding agency know exactly which up-and-coming firms to direct funding toward? (1985:186).

The outcome of the market process is the only way to answer the economic question of which industries should be promoted, regardless of how intelligent the planners might be. 
There is evidence of planning bureaus' failures in East Asia to consistently pick winners. Some of East Asia's most successful companies were discouraged by government planning agencies and other large companies that were supported consistently failed to become profitable. When Sony was only a small electronics firm in the early 1950s they needed government permission in order to get the rights to manufacture transistors from Western Electric. MITI refused arguing that the technology was not impressive enough and it took Sony over two years before they were eventually able to persuade MITI to allow them to obtain the rights (Henderson: 1993). Of course Sony went on to become an extremely successful international business despite MITI's discouragement. In the mid fifties MITI tried to make the auto industry produce a prototype "people's" automobile so it could choose the winning firm and make it the single producer (Henderson: 1993). Then later in the 1960s MITI attempted to prevent auto manufacturers from entering the export market and then attempted to force ten auto firms to merge into Nissan and Toyota (Lavoie 1985:195). Luckily the Japanese auto firms resisted all of these interventions and went on to become one of Japan's most successful industries. Korea provides an example where the government continually intervenes to try to create a winner in the ship building industry, yet fails. The large subsidies have given Korea the second largest ship building industry in the world (Choi 1994:241). Yet the industry needs periodic bailouts to stay in business. (Choi 1994:241). ${ }^{10}$

Although the market can demonstrate failures of development planning, its not possible to identify successes. Henderson (1993) writes,

Between 1953 and 1955 MITI did persuade the government's Japanese Development Bank to lend money to four industries-electric power, ships, coal, and steel. Some 83 percent of JDB financing over that period went to those four industries. But even with hindsight, what has not been established is whether those were good investments.

The calculation and knowledge problem implies that we can never determine that they were good investments for theoretical reasons. We can point to evidence of failures in calculation, because firms demonstrate they should exist as structured by succeeding in the free market despite discouragement by the government or when firms continually subsidized by the government fail to become privately profitable. In both cases feedback from the market indicates a knowledge failure on the part of the planners. Successful planning, however, cannot ever be established by observing that a subsidized firm eventually becomes privately profitable. No market feedback mechanism is in place to show that the gain in the subsidized industry is greater than the opportunity cost of the industry that would have developed in the subsidy's absence. Although observing failures in development planning illustrates the knowledge problem, there is no way to establish which of the industries that are apparent "successes" should have been created, so they are not ever proof of planning's success.

Advocates of development planning must establish how agencies acquire the knowledge to plan on theoretical grounds. Lessons from the socialist calculation debate show that the market process is necessary to generate the relevant knowledge for economic calculation. Attempts to guide the market through selective state development planning suffer from the same knowledge problem that socialist planners do. Gaining the knowledge necessary to direct the economy is impossible before the market process produces it. All attempts to 
direct the market through state planning must fail because they cannot acquire the necessary knowledge.

\subsection{Public Choice Incentive Problem}

Why would state development planners only subsidize industries that best promote growth even if they could figure out which industries they were? Buchanan and Tullock (1962) advanced the idea that politicians should be modeled as rational self-interested individuals who respond to incentives. Olson (1965) further showed that the logic of interest group pressure causes these self-interested politicians to concentrate benefits in the hands of a few while dispersing costs over the general population. Why would state development planning bureaus promote growth, a general interest, while ignoring political incentives that encourage them to concentrate benefits on the most politically beneficial industries? ${ }^{11}$

Wade (1990) attributes East Asia's success in overcoming the incentive problem to the fact that East Asian states are relatively centralized and insulated from society or "hard."12 Hard states are created by a number of factors, some which were present in many of the East Asian countries during their development. ${ }^{13}$

In particular, most states had experienced large social dislocation, which breaks up organized interest groups and allows the state to focus on promoting more encompassing interests (Olson 1982). Through Japanese occupation and then allied victory, World War II caused this type of reorganization of interests in most East Asian countries. Dislocation may have helped East Asian countries to overcome both general forms of rent seeking behavior and also those associated with state development planning. ${ }^{14}$ Wade focuses on the formation of encompassing interests, saying,

By constructing corporatist political arrangements before interest groups began to gain or regain strength, they could channel and restrain demands placed upon the state as those demands grew. One great advantage of corporatist arrangements is that the demands emanate from relatively 'encompassing' organizations, whose memberships make up a sizable portion of the whole society. They are therefore constrained in the extent to which they use their power to urge measures which benefit their members at the expense of national income and productivity (1990:339).

Favorable conditions present in East Asia for a period of time may have minimized rent seeking, but it does not mean rent seeking was entirely eliminated or that favorable conditions will exist perpetually. In some East Asian countries these interest group problems have been becoming more evident in recent years. Although Naka (1994, 2002), attributes much of Japan's success to lack of narrow interest groups in post war years, during the 1990s recession, repeated fiscal stimulus packages have focused on the construction industry, one of the ruling liberal democratic party's closest supporters (Powell 2002).

Rent seeking also occurred in Korea. As much as 10 percent of all foreign loans were kept by President Park's government for personal and political uses (Choi 1994:240). Choi also found that the pricing of foreign capital goods was between 20 percent and 100 percent higher in many public projects than the norm, and the difference was kicked back to key 
figures in the ruling party (1994:240-241). Evidence also suggests that owners of big business bribed government officials to get access to government rationed credit that was priced well below black market rates. Also, while there was high inflation during the 1960s and 1970s the government forced citizens to buy long-term bonds while giving low or 0 percent interest rates on loans to favored businessmen (Choi 1994:241, 250). Choi summarized the rent seeking activity in Korea, writing "It is not that South Koreans avoided rent seeking, but that the dominant group monopolized it, claming the lion's share of the gains from economic growth" (1994:249). Although monopolized rent seeking may lead to a longer time horizon for rulers and better promote development than decentralized rent seeking, Korea illustrates that even relatively "hard" states are not immune from rent seeking inefficiencies when they engage in industrial development planning.

Although favorable conditions may have minimized incentive problems facing state development planning agencies for a period of time, the problem was not entirely eliminated and meaningful development was not promoted by state planning agencies. We have seen that state planning bureaus are unable to overcome the knowledge problem. ${ }^{15}$ This should make us skeptical that state development planning was responsible for the East Asian development miracle.

\section{Evidence from East Asia}

East Asian countries have experienced dramatic increases in their standard of living. Figure 1 shows large improvements in levels of per capita income during the past 25 years. Johnson (1982), Amsden (1989), and Wade (1990) have documented that some state development planning occurred in Japan, Korea, and Taiwan. Stiglitz is correct when he writes, "The controversy surrounds two questions - the counterfactual and the aggregative quantitative significance of these interventions" (2001:518). We must determine to what extent the planning actually interfered with market forces - the quantitative - and to what extent these East Asian countries could have developed without state planning-the counterfactual.

To the extent that state development planning existed, we have shown that it cannot utilize the knowledge that the free market can in solving the economic problem of promoting growth that satisfies consumers' subjective wants. The technical knowledge generated by engineers is useless for solving the economic problem. Technical knowledge can be used to promote industrialization, the creation of factories and products, though they will not correspond to satisfaction of consumers' most urgent wants.

\subsection{Industrialization or Development}

Real economic development consists of the ability to satisfy greater levels of consumers' subjective wants. Unfortunately, no single and objective way exists to measure consumer subjective want satisfaction. Imperfect proxies exist, the best of which focus on consumers' standards of living.

Wade's (1990) data indicating the success of industrial policy in East Asian countries focuses on industry output data instead of measures of consumer welfare. Wade (1990), following Johnson (1982), writes, “The top priority of state action, consistently maintained, 
is economic development, defined for policy purposes in terms of growth, productivity, and competitiveness rather than in terms of welfare" (p. 25). This type of data does not actually measure success in solving the economic problem. It indicates how well the state has solved particular technical problems, such as how much steel was produced, without regard for the opportunity cost in consumer welfare. ${ }^{16}$

Measures show that consumers' standard of living in East Asia have improved over the last fifty years. They also indicate that other measures, less focused on consumer welfare, may overstate the amount of development East Asia achieved. ${ }^{17}$

Japan's GDP per capita statistics are one example of how development can be overstated. Many industrial policies in East Asia have placed tariffs on imports, raising the price of consumer goods in their home country to promote the development of businesses. But tariffs also limit the well-being of the average consumer in the society. When income levels are adjusted for purchasing power differences, caused in part by the industrial policies themselves, consumers' standard of living can be much lower. In Japan's case, GDP per capita was $\$ 37,522$ in 2000 , but when the figure is adjusted for purchasing power it falls to $\$ 25,280$ (World Bank 2003). Figures that fail to adjust for purchasing power parity in Japan overstate the level of consumer well-being by more than 40 percent. $^{18}$

Another way to measure consumer welfare is to look at what people own. Assuming Asians have similar tastes and preferences for goods as consumers in the U.S., we would expect the difference in ownership rates of goods to be approximately proportional to the difference in GDP per capita. World Bank data shows that ownership rates for televisions, radios, and automobiles are lower in some East Asian countries than is predicted by the difference in their GDP compared to the U.S. While Japan's GDP per capita is reported as 140.6 percent of the U.S. GDP per capita in 2000, Japanese citizens only owned 45.1 percent of the number of radios per person and 84.9 percent of the number of televisions per person (World Bank 2003). Table 1 reports similar findings for other East Asian countries over the past 20 years. Although lower automobile ownership rates make sense in some East Asian countries, such as small island nations like Hong Kong, why television and radio ownership rates are lower is less obvious. This type of data indicates that some of the "development" in these countries may not translate into increases in consumer well-being.

Industrial planning can solve the technical problem of increasing output, but not the economic problem of only increasing output where consumers most urgently want it without leaving other more urgent wants left unsatisfied. Industrial planning drives a wedge between measured increases in output and actual consumers' standard of living. ${ }^{19}$ The anecdotal evidence above suggests that this happened to some extent in East Asia. This is not to say a dramatic increase in well-being has not occurred; much evidence suggests it has. This only indicates that the industrial planning present has decreased consumers' standard of living to some extent.

\subsection{Economic Freedom or Planning}

Little doubt exists that East Asian countries' standards of living have increased despite the difficulty of measuring consumer subjective want satisfaction. An important question is how pervasive government planning was in these economies. If we find that while some state 
Table 1. GDP and Consumer Goods Ownership as a Percent of U.S.

Rates.

\begin{tabular}{lcccr}
\hline & GDP $(\%)$ & Radio $(\%)$ & TV $(\%)$ & Cars (\%) \\
\hline Hong Kong & 53.8 & 1980 & 39.3 & 7.6 \\
Japan & 134.7 & 33.9 & 95.7 & 37.8 \\
Korea & 18.6 & 47.2 & 29.4 & 1.2 \\
Singapore & 52.4 & 18.6 & 55.3 & 12.2 \\
& & 1990 & & \\
Hong Kong & 72.0 & 31.4 & 36.5 & 7.3 \\
Japan & 152.8 & 42.4 & 79.1 & 49.4 \\
Korea & 30.5 & 47.7 & 27.1 & 8.4 \\
Singapore & 67.4 & 27.5 & 44.0 & 15.6 \\
& & 2000 & & \\
Hong Kong & 77.5 & 32.3 & 57.8 & \\
Japan & 140.6 & 45.1 & 84.9 & \\
Korea & 41.5 & 48.8 & 42.7 & \\
Singapore & 89.4 & 31.7 & 35.6 & \\
\hline
\end{tabular}

Source: World Bank World Development Indicators, 2003.

planning existed, on balance East Asia countries relied more on markets, were more free economically, and had stronger private property rights than other slower growing areas of the world, we can explain East Asia's growth despite the existence of some state planning.

Wade correctly points out that, "The key question is what has determined the level and composition of investment in these countries. There are plenty of facts about Taiwan, Korea, and Japan which better fit the neoclassical FM and SM theories than the political economy GM theory." But he further writes, "But it is clear both that less economic liberalization occurred in the 1960s and 1970s than neoclassical accounts suggest, and that much government intervention has gone beyond the limits of 'good' neoclassical interventions. Government resources and influence have prompted investments to be undertaken which would not have been undertaken in strictly FM or SM conditions" (1990:342). We need to determine if while the governments were doing some things to affect investment, they also left more room for the market to operate than governments in other industrialized nations. Wade dismisses the argument that the countries grew in spite of the planning, writing,

The balance of presumption must be that economic liberalization matters less in an explanation of East Asian success than neoclassical accounts suggest, and that actual performance was better than it would have been with FM or SM polices alone. ... But we should reject the unargued assertion that "without MITI Japan would have grown at 15 percent per annum" instead of only 10 percent; or that for Korea, "success has been achieved despite intervention." It is less plausible to say that the three countries with arguably the best development performance on record would have had still better 
performance had their governments intervened less, than to say that interventions made with the clear intention of accelerating development and formulated by a coherent organization did indeed have the intended effect. Those who deny this are claiming extraordinary ability to forecast historically unprecedented performance (1990:342$343)^{20}$

Wade can make this claim only because he fails to consider that these East Asian countries might have had industrial planning simultaneously with still freer economies than other countries in the world.

Hong Kong is particularly troubling for those who claim state development planning caused East Asian growth. Hong Kong is typically held up as an example of a textbook free market capitalist economy. Wade writes, "The Hong Kong case does not support the proposition that because Hong Kong did as well as the others without industrial policies, the industrial policies of the others could not have made much difference" (1990:343). Wade dedicates two and a half pages to proving that Hong Kong is not a free market economy. He writes,

It is true that the formal institutions of government perform mainly custodial functions and that Hong Kong has no controls over imports, foreign exchange, foreign investment, and wages and prices. Tax revenues to GNP are very low, at 13.7 percent in 1977, compared to Taiwan's 24.2 percent. But to conclude from this that Hong Kong is close to a free market economy is misleading (1990:331-332).

The one paragraph of evidence supporting this case mentions revenue raised through government granted leases, control of the housing market through a large amount of public housing, and immigration control manipulation. This makes Hong Kong less than a perfect capitalist country. It does not mean that Hong Kong is far from a totally free market economy. In fact, the Fraser Institute's Economic Freedom of the World Annual Report has ranked Hong Kong the most economically free country in the world from 1970 to present. ${ }^{21}$

Although one cannot accurately claim that Hong Kong did not grow, or that it was not an example of a free market economy, that does not prove that the development in other East Asian countries did not occur because of state planning. ${ }^{22}$ After all, Hong Kong is a small nation and other regional effects may have influenced its growth.

The most troubling fact for theories that claim East Asian development occurred because of state development planning is that the very economies that are supposed to be examples of state planning are some of the most free market economies in the world.

Wade (1990) specifically says that to look at only government as a percent of GDP to determine the level of government activity in the economy is not enough. Just because a country may have a low percent of GDP consumed by government, regulations could be severely affecting market outcomes. The Economic Freedom of the World annual report, although an imperfect measure, is the best overall measure of government interference and direction of the economy available. This broad index covers five major areas of the economy, including size of government: expenditures, taxes and enterprises; legal structure and security of property rights; sound money; freedom to trade with foreigners; and regulation 
of credit, labor and business. These five major areas are made up of 21 components and 37 distinct pieces of data.

Wade's (1990) evidence that East Asian countries were cases of state led development focuses on the ways the governments interfered with their economies. Equally important evidence from all of these economies is what their governments did not interfere with. Looking at the Economic Freedom of the World report allows us to determine whether the overall industrial structures in these countries were more influenced by free markets or state interference.

The Economic Freedom of the World holds all countries to the same standards when measuring freedom. It could be that because of factions and a heterogeneous population, some countries are not able to achieve as high of a level of freedom as others and that what is observed as government interference in the economy could actually be preventing further fighting between factions that would result in even less freedom. Naka (2002) shows post WWII Japan as an example of this. He shows that there was a large rural and agricultural faction that could have benefited by exploiting the more business oriented elite minority. He argues the two groups reached a Coasian bargain where subsidies through the political process were given to the rural majority in exchange for their not seizing the minority's wealth in a one shot taking. The deal promoted economic growth, benefited both parties, and possibly prevented more violent or decentralized clashes between factions that could have resulted in less freedom. Despite this, such subsidies would adversely impact measured freedom. This does not however undermine the argument the economic freedom promotes growth. It simply shows that some countries were achieving the greatest level of freedom they could, given the politics and demographics in their country. If they could achieve more freedom, they could grow even faster. ${ }^{23}$

Using the Economic Freedom of the World report, we find that Johnson (1982), Amsden (1989), and Wade's (1990), own examples of countries in which state development planning was responsible for growth rank very high in economic freedom. In 1970 Japan was ranked the seventh most free country in the world, Taiwan was the sixteenth freest, and even Korea was in the top 20 percent, ranking thirty-first. Other high growth East Asian countries such as Hong Kong and Singapore have also ranked near the top of the index from its beginning in 1970 to present (See Table 2).

Table 2. Fraser economic freedom index score and ranking.

\begin{tabular}{llllllll}
\hline & 1970 & 1975 & 1980 & 1985 & 1990 & 1995 & 2000 \\
\hline Hong Kong & $8.4(1)$ & $8.5(1)$ & $8.7(1)$ & $8.4(1)$ & $8.3(1)$ & $9.1(1)$ & $8.8(1)$ \\
Indonesia & $4.8(43)$ & $5.0(48)$ & $5.0(66)$ & $6.0(29)$ & $6.4(30)$ & $6.5(41)$ & $6.0(77)$ \\
Japan & $7.2(7)$ & $6.4(14)$ & $6.9(10)$ & $7.0(13)$ & $7.3(7)$ & $7.0(29)$ & $7.3(24)$ \\
Korea, Rep. & $5.9(31)$ & $5.3(41)$ & $5.7(37)$ & $5.8(38)$ & $6.1(38)$ & $6.4(43)$ & $7.0(38)$ \\
Malaysia & $6.5(18)$ & $6.3(15)$ & $6.9(10)$ & $7.0(13)$ & $7.2(10)$ & $7.3(18)$ & $6.7(51)$ \\
Singapore & $7.2(7)$ & $7.1(7)$ & $7.4(5)$ & $7.8(3)$ & $8.2(2)$ & $8.7(2)$ & $8.6(2)$ \\
Taiwan & $6.6(16)$ & $5.6(29)$ & $6.4(17)$ & $6.7(17)$ & $6.9(16)$ & $7.1(25)$ & $7.2(30)$ \\
Thailand & $6.1(27)$ & $5.7(26)$ & $5.9(26)$ & $6.0(29)$ & $6.6(23)$ & $7.1(25)$ & $6.6(56)$ \\
\hline
\end{tabular}

Source: Economic Freedom of the World 2002 Annual Report. 


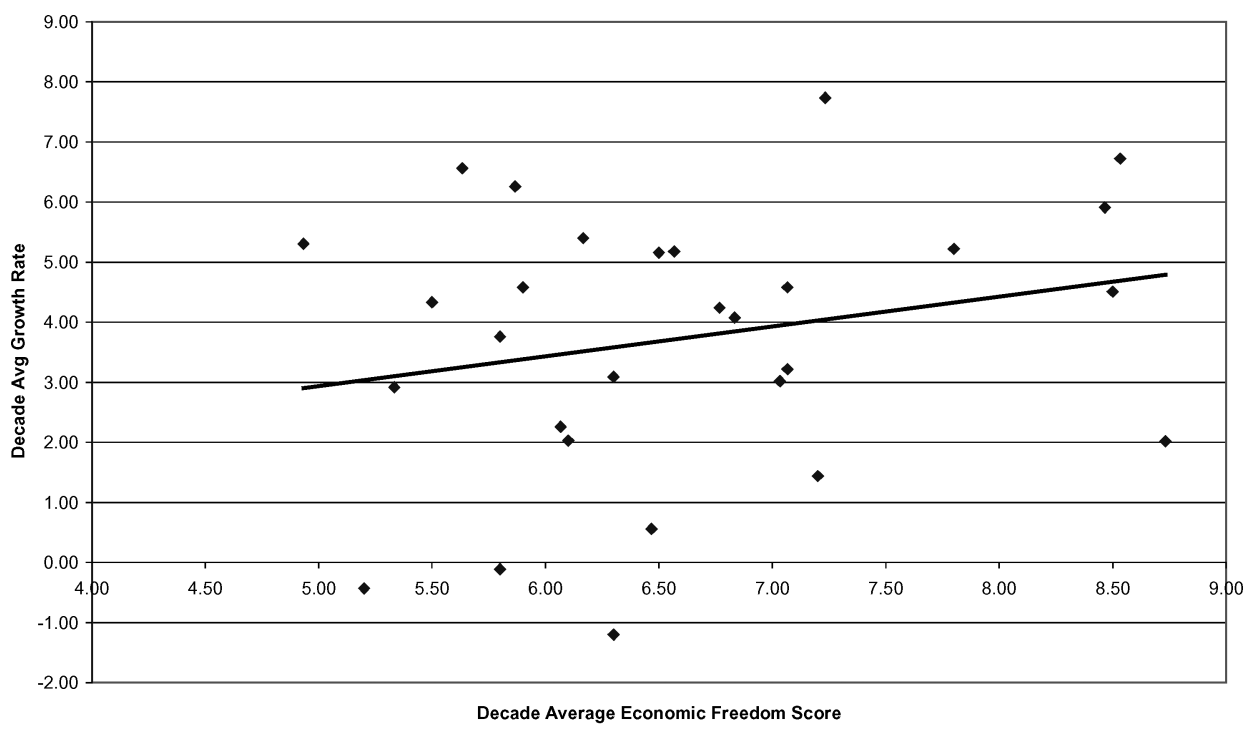

Sources: Fraser Economic Freedom of the World 2002, World Bank World Development Indicators

Figure 2. East Asian Economic freedom and growth.

Many studies have shown that increases in well-being and growth rates are correlated with higher levels of economic freedom and property rights. ${ }^{24}$ This is not surprising given arguments about the importance of markets in solving the knowledge and incentives problems pointed out earlier in this paper. The general results hold when we look at the subset of East Asian countries over the last thirty years. While East Asia experienced a high level of growth in general, the countries that were most free generally achieved higher rates of growth. Figure 2 plots the economic freedom and growth rates achieved by nine East Asian countries for three different decades. ${ }^{25}$ Each data point in the chart is a country's average growth rate for one decade, and average freedom score for the decade. ${ }^{26}$ Despite a few outliers, the chart illustrates that the general relationship between economic freedom and growth rates held for the subset of East Asian countries from 1970 through 2000. In East Asian countries generally, and even in those countries that are claimed as industrial planning successes, high levels of economic freedom have been present.

No tension exists between the two main points in this section of the paper. The existence of state development planning in East Asia promoted industrialization, not growth, and East Asian countries grew not because of state development planning but because they were some of the most free market countries in the world. The East Asian countries are not perfect capitalist countries with no government interventions; they do not score perfectly on the economic freedom indexes. Part of the reason they do not score perfectly is that they have intervened in their economies with development planning and related measures. Other than these interventions, the East Asian countries are very economically free. This has allowed them to grow faster than nations in other regions. 


\section{Conclusion}

State development planning cannot promote real economic growth. Advocates of development planning fail to recognize that the same calculation problem that Mises and Hayek outlined in the socialist calculation debate also applies to more limited attempts at planning the market process. The knowledge necessary for solving the economic problem of how to satisfy the most urgently felt wants without leaving any more urgent want unsatisfied requires the price knowledge that the market generates. Any attempt to 'guide' the market operates without this knowledge. The technical types of knowledge Wade (1990) addresses are simply not adequate to solve the economic problem confronting development planners.

East Asia's experience is consistent with this view. Although some state development planning did exist in East Asian countries, it was not responsible for the growth that occurred. To the extent that governments did interfere with the market's process, they promoted industrialization, not consumer-satisfying development. Although Wade (1990) points to various increases in measures such as exports, steel production, and automobile production, measures that focus on consumer well-being show that growth might be overstated. While real GDP per capita increased greatly, when we adjust for purchasing power, or consumer goods ownership, standards of living are lower.

Authors who attribute East Asia's success to developmental planning overlook important data. Although some state industrial planning did exist in East Asian countries, when these countries were growing they were some of the most free market in the world. Hong Kong and Singapore are consistently ranked the top two freest countries in the world, and in 1970, when Japan and Taiwan were growing quickly, they were ranked seventh and sixteenth. Even Korea ranked in the top 20 percent. Although state development planning did exist in these countries, overall broader measures of the market's relative sphere of influence in these countries show that they were far more market oriented than slower growing areas of the world.

To the extent that the development of the East Asian countries was a miracle, it was because the free market was the driving force. Some external factors, such as lower initial GDP and social dislocation to break up entrenched interests, certainly have had additional positive effects. The evidence from East Asia is consistent with the view that development is promoted through free markets and not state industrial development planning.

\section{Acknowledgment}

The Author thanks Peter Boettke, Donald Boudreaux, Todd Zywicki, an anonymous referee, the participants at the Austrian Scholars conference 2003, and the participants at the Association of Private Enterprise Education conference in Las Vegas 2003 for helpful suggestions earlier drafts. I also thank the Mercatus Center's Global Prosperity Initiative for financial support. Any remaining errors are my responsibility.

\section{Notes}

1. Wade wrote, "Had the governments not abandoned some basic principles of the East Asian model—above all, the principle of strategic rather than open-ended integration into world financial markets-the economies 
would probably not have experienced a serious crisis, although they would have grown more slowly" (2000: 107).

2. Furman and Stiglitz wrote, "We argue that one of the most important developments was the rapid liberalization of financial markets, both domestic and international, without the corresponding development of proper regulation or supervision" (1998:9). Wade similarly states, "Asian governments are deeply implicated in the crisis for opening the financial system quickly in the 1990s without linking the pace of the opening to the build-up of effective rule-based (rather than relationship-based) governance of financial markets" (2000:107).

3. Adam Smith recognized this point more than 200 years ago when he wrote, "Consumption is the sole end and purpose of all production; and the interest of the producer ought to be attended to, only so far as it may be necessary for promoting that of the consumer" (1776:715).

4. Again Smith (1776:717) anticipates this problem, writing, "It cannot be very difficult to determine who have been the contrivers of this whole mercantile system; not the consumers, we may believe, whose interest has been entirely neglected; but the producers, whose interest has been so carefully attended to; and among this latter class our merchants and manufacturers have been by far the principal architects."

5. Advocates of developmental planning miss the link between the informational argument against socialism and how it bears on interventionist planning. They actually get the argument backward. Vartiainen (1999) favorably cites Stiglitz's, Whither Socialism? (1994) and writes, "While a deeper understanding of incentive mechanisms and information economics has discredited the feasibility of comprehensive central planning and public ownership as viable economic strategies, the emphasis of the most interesting modern economics has also shifted in a way that makes the interventionist case more appealing than it used to be" (1999:205).

6. Similarly, Johnson (1999:59) characterizes American private business managers as "short-term profit maximizers." Stiglitz (1996) takes a different angle on the problem, granting longer time horizons to managers but instead claiming capital market imperfection prevents them from sustaining losses in the short run in order to gain higher profits later (159). He does not say how government is able to identify which of these projects should be funded.

7. The charge that businesses are "short-term" profit maximizers is particularly odd since Wade and others offer no evidence or argument to prove the charge and it is so at odds with standard economic theory. Throughout standard economics literature businesses are regarded as long-term profit maximizing. Examples abound, from short-run shut down conditions to why private ownership is good in natural resource economics. If businesses were in fact short-term maximizers, hardly any would be started at all, since most lose money initially. In fact, short-term maximizing at the expense of long-run optimality is usually attributed to the political process in which self-interested government officials have only temporary control of the government to extract resources. And this is precisely the solution Wade offers to counter the unproved assertion that business are short-term maximizers.

8. Stiglitz similarly says, "The criticism of industrial policies as misguided attempts to pick winners ignores the broader range of government actions, such as its role in spearheading the expansion of certain manufacturing sectors. "Picking winners" seems to imply culling from a fixed pool of applicants to find those with the highest long-run social returns. East Asian government have instead performed an entrepreneurial role" (1996:162). Surely though even in this entrepreneurial role, when one industry is expanded due to government "spearheading" there is an opportunity cost of what the resources would have otherwise gone to. This in no way moves the governments away from the need to "pick winners."

9. Wade writes that governing the market "requires that the agencies be able to recruit from amongst the more gifted members of their generation" (1990:195). Johnson (1982:314) also says that the bureaucracy must be "staffed by the best managerial talent available in the system." Evans (1995:12), writing on the internal organization of development states, says, "highly selective meritocratic recruitment" is used.

10. Although the focus of this paper is East Asia, development planning has failed in many other regions of the world. For evidence of the failure of development planning in Africa see Easterly (2002). For a general overview of the failure of development planning around the globe see Boettke (1994).

11. Most advocates of state development planning recognize this problem. Johnson (1999:48) writes, "The real objection is not to its [state planning's] use as an alternative to or displacement of market forces but that it is more commonly used to protect vested interests than to achieve national development." Johnson asserts that states can structure incentives in a way that will solve the problem and cites Japan as proof. 
12. "The shortest answer to why this type of failure is limited in East Asia is that East Asian states are relatively hard. The position of a state in relation to its society can be thought of as varying along a continuum from decentralized and constrained by social groups, to centralized and relatively insulated from society-from 'soft' to 'hard."' (Wade 1990:337). Evans (1995) deals with the interest group problem slightly differently; he focuses on "embedded autonomy." The bureaucracies must be "embedded in a concrete set of social ties that binds the state to society and provides institutionalized channels for the continual negotiation and renegotiation of goals and policies" (1995:12). But similar to Wade (1990), they must also be autonomous so that they are not captured by interest groups. "Either side of the combination by itself would not work" (1995:12)

13. These factors include: massive social dislocation occurring within the past 50 years; the existence of serious military threat; support from the international state system for a concentration of social control in the hands of the state; the existence of a social grouping with people sufficiently independent of existing bases of social control and skillful enough to execute the grand designs of state leaders; and skillful leaders whose ideology favors strong state control (Wade 1990:339).

14. In fact, Olson (1982) attributes the rapid growth in both Asian and European countries affected by WWII to the breaking up of entrenched interests without giving any credit to industrial policy. To the extent that the break up of interest groups limited rent seeking, that by itself could have caused the East Asian growth. There is some evidence to support this since other countries such as West Germany that benefited from the breakup of interest groups achieved high rates of growth without the same level of industrial planning as East Asia.

15. The fact that the knowledge problem cannot be overcome actually leads to the interest group problems. If decisions cannot be based on economic calculation, they must be based on something. Political calculations are readily possible and in the interests of the decision-makers. Boettke (2001) states the problem by saying, "Since the economic knowledge necessary to plan the economy rationally will not be available to planners, these decision-makers will be forced to rely on the forms of information that are readily available, which in this context comes in the form of incentives to exercise political power" (p.52).

16. When commenting on the Mercantile system, Adam Smith could have just as aptly been speaking of state development planning when he wrote, "the interest of the consumer is almost constantly sacrificed to that of the producer; and it seems to consider production, and not consumption, as the ultimate end and object of all industry and commerce" (1776: 715).

17. In a review of his 1982 book, Johnson (1999) mentions one reviewer was concerned "That MITI's policies have strengthened the abstract entity called Japan but have not done much to enrich the lives of Japanese consumers and city dwellers. The Japanese people's standard of living did not change anywhere near as much as the change in the Japanese gross national product" (1999:50). Johnson must agree with the observation since he offers no evidence or argument to refute the comment.

18. Similarly, in South Korea Choi (1994) notes that "South Koreans had been forced to pay exorbitant prices for shoddy products in protected consumer goods markets dominated by government-sanctioned monopolies and oligopolies" (p. 251).

19. Nutter (1962) finds evidence of this when examining growth rates in the Soviet Union. He found that the planning in the USSR systematically favored industrialization over consumption and leisure, thus exacting a heavy cost in both resources expended and human suffering (p. 292).

20. Even Stiglitz (2001:518) at least leaves room that the East Asian countries might have grown faster without the planning that occurred, though he does not think it is very probable.

21. Hong Kong has also ranked the most free country in the world by the Heritage Foundation and Wall Street Journal's Index of Economic Freedom since the index was created in 1995.

22. In measures that focus on consumer welfare, such as GDP per capita adjusted by purchasing power parity, Hong Kong is equal or superior to other East Asian countries (See Figure 1).

23. In this case, the subsidies caused Japan to possibly grow faster than if there were more decentralized factions taking the minorities wealth, as in Olson's (2000) roving bandit model, but Japan could have grown even faster if they could have avoided both the decentralized rent seeking, and the bargain the resulted in subsidies. Avoiding both of these problems would have also resulted in higher freedom scores.

24. Studies by Scully (1988 and 1992), Barro (1991), Barro and Sala-I-Martin (1995), Knack and Keefer (1995), Knack (1996), and Keefer and Knack (1997) all show that measures of well-defined property rights, public policies that do not attenuate property rights, and the rule of law tend to generate economic growth. Gwartney, 
Holcombe and Lawson (1998) found a strong and persistent negative relationship between government expenditures and growth of GDP for both OECD countries and a larger set of 60 nations around the world. Norton used the Fraser and Heritage indexes of economic freedom and found that strong property rights tend to reduce the deprivation of the world's poorest people. Grubel (1998) also used the Fraser Institute's index of economic freedom to find that economic freedom is associated with superior performance in income levels, income growth, unemployment rates and human development. Powell (2002) found that income, growth, life expectancy and human development are all associated with higher levels of economic freedom using either the Fraser or Heritage indexes of economic freedom. Berggren (2003) provides a summary of literature that links economic freedom with development.

25. The plotted countries had both World Bank growth rates and economic freedom index scores available. These are Japan, Korea, Hong Kong, Singapore, Indonesia, Malaysia, Thailand, Philippines, Papua New Guinea and Fiji.

26. The points were plotted for decade averages to smooth out some of the variations that occur in business cycles. We are interested in the institutional environment and long term growth. Each country has 3 points plotted on the chart, one for their 1970s avg, one for the '80s and one for the '90s (except Papua New Guinea, which has two data points because of missing data for the '70s).

\section{References}

Amsden, A. (1989) Asia's Next Giant: South Korea and Late Industrialization. New York, NY: Oxford University Press.

Barro, R. (1991) "Economic Growth in a Cross Section of Countries.” Quarterly Journal of Economics, 106: 407-443.

Barro, R. and Sala-i-Martin, X. (1995) Economic Growth. New York, N.Y.: McGraw- Hill.

Berggren, N. (2003) "The Benefits of Economic Freedom: A Survey.” Independent Review, 8(2): 193-211.

Buchanan, J. and Tullock, G. [2001 (1962)] The Calculus of Consent. Ann Arbor, MI: University of Michigan Press.

Boettke, P. (1994) The Collapse of Development Planning. New York, NY: New York University Press.

Boettke, P. (2001) Calculation and Coordination. New York, NY: Routledge.

Choi, Y. (1994) "Industrial Policy as the Engine of Economic Growth in South Korea: Myth and Reality." In:

Boettke, P. (Ed.) The Collapse of Development Planning New York, NY: New York University Press.

Easterly, W. (2002) The Elusive Quest for Growth. Cambridge, MA: MIT Press.

Evans, P. (1995) Embedded Autonomy. Princeton, NJ: Princeton University Press.

Furman, J. and Stiglitz, J (1998) "Economic Crises: Evidence and Insights from East Asia." Brookings Papers on Economic Activity, 1998(2): 1-114.

Grubel, H. (1998) "Economic Freedom and Human Welfare: Some Empirical Findings." Cato Journal, 18(2): 287-304.

Gwartney, J., Holcombe, R., and Lawson, R. (1998) "The Scope of Government and the Wealth of Nations." Cato Journal, 18(2): 163-190.

Hayek, F. (1935) Collectivist Economic Planning. London, UK: George Routledge \& Sons, Ltd.

Hayek, F. (1940) "The Competitive 'Solution." Economica, 8(26).

Hayek, F. (1945) "The Use of Knowledge in Society." American Economic Review, 35(4): 519-530.

Hayek, F. (1978) “Competition as a Discovery Procedure.” In New Studies in Philosophy, Politics, Economics and the History of Ideas. Chicago, IL: University of Chicago Press.

Henderson, D. [2002 (1993)] "Japan and the Myth of MITI." The Concise Encyclopedia of Economics. Indianapolis, IN: Liberty Fund. Available at http://www.econlib.org/library/Enc/JapanandtheMythofMITI.html

Johnson, C. (1982) MITI and the Japanese Miracle: The Growth of Industrial Policy, 1925-1975. Stanford, CA: Stanford University Press.

Johnson, C. (1999) “The Developmental State: Odyssey of a Concept.” In: Woo-Cumings, M. (Ed.) The Developmental State. Ithaca, NY: Cornell University Press.

Keefer, P. and Knack S. (1997) "Why Don't Poor Countries Catch-Up? A Cross National Test of Institutional Explanations.” Economic Inquiry, 35: 590-602. 
Knack, S. (1996) "Institutions and the convergence hypothesis: The cross-national evidence." Public Choice, 87: 207-228.

Knack, S. and Keefer, P. (1995) "Institutions and Economic Performance: Cross Country Tests Using Alternative Institutional Measures.” Economics and Politics, 7: 207-227.

Krugman, P. (1994) Peddling Prosperity. New York, NY: W.W. Norton \& Company, Inc.

Lavoie, D. (1985) National Economic Planning, What is Left? Cambridge, MA: Ballinger Publishing Company. Mises, L. [1990 (1920)] Economic Calculation in the Socialist Commonwealth. Auburn, AL: Ludwig Von Mises Institute.

Mises, L. [1998 (1949)] Human Action. Auburn, AL: Ludwig Von Mises Institute.

Naka, S. (1994) "The Political Economy of Post-World War II Japanese Development: A Rent-Seeking Perspective.” In Boettke, P. (Ed.) The Collapse of Development Planning. New York, NY: New York University Press.

Naka, S. (2002) "The Postwar Japanese Political Economy in an Exchange Perspective." The Review of Austrian Economics, 15(2/3): 175-197.

Norton, S. (1998) "Poverty, Property Rights, and Human Well-Being: A Cross National Study." Cato Journal, 18(2): 233-245.

Nutter, W. (1962) The Growth of Industrial Production in the Soviet Union. Princeton, NJ: Princeton University Press.

O’Driscoll, G., Holmes, M. and O’Grady, M. (2002) 2002 Index of Economic Freedom. Washington, DC: Heritage Foundation and Wall Street Journal.

Olson, M. [1971 (1965)] The Logic of Collective Action. Cambridge, MA: Harvard University Press.

Olson, M. (1982) The Rise and Decline of Nations. New Haven, CT: Yale University Press.

Olson, M. (2000) Power and Prosperity. New York, NY: Basic Books.

Powell, B. (2002) "Explaining Japan's Recession.” Quarterly Journal of Austrian Economics, 5(2) (Summer 2002): $35-50$

Powell, B. (2002) "Private Property Rights, Economic Freedom, and Well-Being." Economic Education Bulletin, American Institute for Economic Research, 42(11).

Scully, G. (1988) “The Institutional Framework and Economic Development.” Journal of Political Economy, 96: $652-662$.

Scully, G. (1992) Constitutional Environments and Economic Growth. Princeton NJ: Princeton University Press. Smith, A. [1994 (1776)] An Inquiry into the Nature and Causes of the Wealth of Nations. Modern Library edition, Edwin (Ed.) Cannan. New York, NY: Random House.

Stiglitz, J. (1994) Whither Socialism? Cambridge, MA: MIT Press.

Stiglitz, J. (1996) "Some Lessons from the East Asian Miracle." The World Bank Research Observer, 11(2): 151-177.

Stiglitz, J. (1999) "Lessons from East Asia.” Journal of Policy Modeling, 21(3): 311-330.

Stiglitz, J. (2001) "From Miracle to Crisis to Recovery: Lessons from Four Decades of East Asian Experience." In: Stiglitz, J. and Yusuf, S. (Ed.) Rethinking the East Asian Miracle. New York, NY: Oxford University Press.

Vartiainen, J. (1999) “The Economics of Successful State Intervention in Industrial Transformation.” In: WooCumings, M. (Ed.) The Developmental State. Ithaca, NY: Cornell University Press.

Wade, R. (1990) Governing the Market. Princeton, NJ: Princeton University Press.

Wade, R. (1998) "From 'miracle' to 'cronyism': explaining the Great Asian Slump." Cambridge Journal of Economics, 22: 693-706.

Wade, R. (2000) "Wheels Within Wheels: Rethinking the Asian Crisis and the Asian Model." Annual Review of Political Science, 3: 85-115.

Woo-Cumings, M. (1999) The Developmental State. Ithaca, NY.: Cornell University Press. 